\title{
Kebijakan Formulasi Undang-undang Narkotika Dalam Legalisasi Penggunaan Ganja Sebagai Bahan Pengobatan di Indonesia
}

\author{
Oleh Leonie Lokollo ${ }^{1}$, Yonna Beatrix Salamor ${ }^{2}$, Erwin Ubwarin ${ }^{3}$
}

\section{leonie.lokollo@fhukum.unpatti.ac.id ${ }^{1}$}

Ilmu Hukum, Fakultas Hukum, Universitas Pattimura ${ }^{123}$

\begin{abstract}
ABSTRAK
Ganja merupakan jenis narkotika terlarang di Indonesia, hal ini diatur dalam Lampran I Undang-undang Nomor 35 Tahun 2009 tentang Narkotika, ganja merupakan narkotika Golongan I yang tidak bisa digunakan untuk keperluan medis. Bahkan ada beberapa orang yang menggunakan sebagai bahan medis untuk menangani penyakit mereka padahal belum legal di Indonesia. Penulisan ini memakai metode yuridis normatif dengan tujuan untuk memberikan masukan kepada Pemerintah Republik Indonesia maupun Dewan Perwakilan Rakyat tentang pentingnya ganja sebagai bahan medis. Pembahasan penulisan ini menemukan bahwa ada beberapa penelitian yang membuktikan bahwa ganja berkhasiat menjadi obat untuk para pasien dan terbukti sembuh contohnya penyakit Alzheimer, Kanker, HIV/AIDS, epilepsy, Parkinson disease, Hepatitis C dan glaukoma, bahkan di Kota Ambon, perna menggunakan ganja sebagai obat herbal untuk beberapa penyakit ganja sudah diakui khasiatnya dan legal dibeberapa Negara. Untuk itu ganja perlu dimasukan kedalam Narkotika Golongan II atau Golongan III supaya dapat digunakan sebagai bahan medis.

Kata Kunci : Kebijakan Hukum Pidana, Ganja
\end{abstract}




\section{ABSTRACT}

Marijuana is a prohibited type of narcotics in Indonesia, this is regulated in Lampran I of Law Number 35 Year 2009 concerning Narcotics, marijuana is a Group I narcotics that cannot be used for medical purposes. There are even some people who use it as medical material to deal with their disease even though it is not yet legal in Indonesia. This writing uses the normative juridical method with the aim of providing input to the Government of the Republic of Indonesia and the House of Representatives on the importance of marijuana as medical material. The discussion of this paper found that there are several studies that prove that marijuana has the efficacy of being a drug for patients and proven to be cured for example Alzheimer's disease, Cancer, HIV / AIDS, epilepsy, Parkinson's disease, Hepatitis $C$ and glaucoma, even in Ambon City, perna used marijuana as herbal remedies for some cannabis have been recognized for their efficacy and are legal in several countries. For this reason, marijuana needs to be included in Narcotics Group II or Group III so that it can be used as medical material.

Key words: Criminal Law Policy, Cannabis

\section{Pendahuluan}

Wacana legalisasi ganja kari pada umumnya dan daging menjadi perbincangan di Indonesia bebeknya sagat lembut karena dan timbul pro dan kontra, sebagian dimasak dengan biji ganja.

kalangan di Indonesia ingin melegalkan ganja, dan sebagaian mengangap bahwa ganja berbayasa bagi generasi Indonesia. Aceh merupakan salah satu Provinsi dengan kuliner dengan bumbu penyedap berbahan dasar ganja, contohnya kari bebek yang kuah kari Perkembangan ganja bukan saja di Aceh, namun juga tumbuh dan berkembang di Ambon, dalam buku Rumphius, ia melakukan penelitian di Ambon kemudian menemukan ada Ambonese Herbal obat yang biasanya digunakan untuk tersebut rasanya lain dengan kuah 
mengobati penyakit, ${ }^{1}$ antara lain Lodoicea maldivica Pers (Kelapa Laut) yang buahnya digunakan untuk Anti-inflamasi dan antipiretik, sedangkan kulit kelapa digunakan untuk penyakit kolera karena mengandung Antibiotic, antidiarrheal. Drynaria sparsisora (Desv.) T. Moore (Paku Layang) digunakan untuk akarnya biasa digunakan untuk meningkatkan nafsu makan, paku layang dapat dimasak dan airnya dapat menurunkan darah tinggi karena mempunyai efek samping Diuretic. Biji Atung digunakan untuk obat Disentri karena mengandung anti-diarrheal, anti-infective, anti-inflammatory. ${ }^{2}$ Rumphius mengatakan bahwa ketika dia sampai ke Ambon dia menemukan pemakaian Cannabis Indica/ Hemp, ganja yang beredar di Ambon digunakan sebagai rekreasi dan medis, ganja yang tumbuh di

1 Rumpf, Georg Eberhard; Beekman, E. M, The Poison Tree Selected Writings of Rumphius on the Natural History of the Indies, University of Massachusetts Press, 1981. Hal 166

2 E.J. Buenz, H.E. Johnson, E.M. Beekman, T.J. Motley, B.A. Bauer, Bioprospecting Rumphius's Ambonese Herbal: Volume I , Journal of Ethopharmacology. (2004)
Ambon, bukan merupakan tanaman endemik dari Ambon, namun bijinya dibawah dari Jawa dan kemudian ditanam di Ambon, menurut Rumphius, ganja dikonsumsi untuk mengobati gonorea, hernia, selain untuk obat (medicamenten) daun ganja juga dikonsumsi dengan dicampur dengan tembakau dan akan menghasilkan halusinasi, atau dalam bahasa ambon melayu hayal, bahasa Indonesia khayal.

Rumpius menemukan bahwa di Ambon tumbuh tiga jenis ganja, yaitu cannabis sativa dan cannabis indica, dan ada satu ganja yang disebutkannya sebagai ganja hutan

\section{Gambar I}

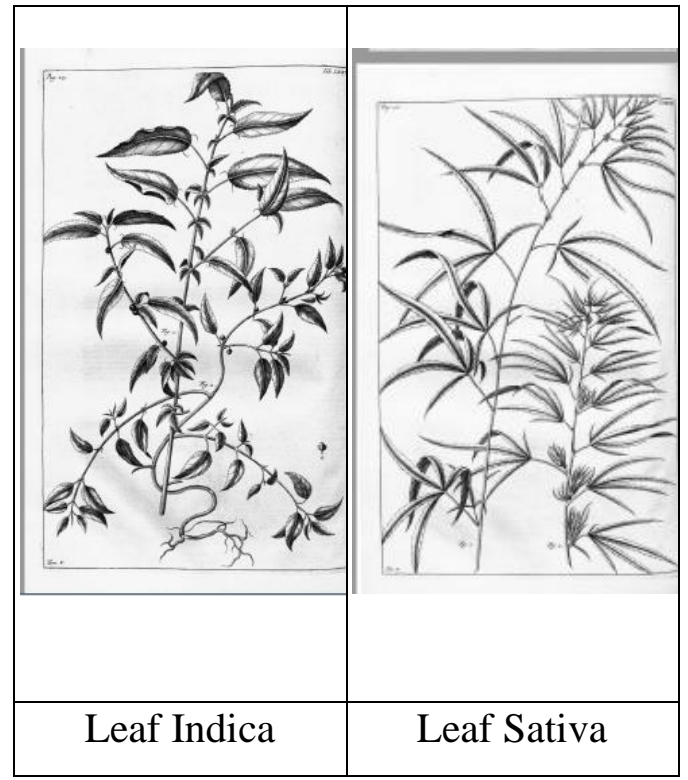


Sumber : Georgius Everhardus Rumphius, Herbarium Amboinense, VOC, Nederland 1741

Jika melihat penjelasan diatas maka perlu adanya kebijakan hukum pidana untuk mengatur penggunaan ganja. Kebijakan hukum pidana (penal policy) bertolak dari pendapat Soedarto, mengandung pengertian: ${ }^{3}$

1. usaha untuk mewujudkan peraturan yang lebih baik sesuai dengan situasi pada suatu saat.

2. kebijakan dari negara, melalui badan-badan yang berwenang menetapkan peraturan yang dikehendaki yang diperkirakan dapat digunakan untuk mengekspresikan apa yang terkandung dalam masyarakat dan untuk mencapai tujuan yang dicita-citakan.

3. bertolak dari pemahaman tersebut, melaksanakan

3 Sudarto, Hukum Pidana dan Perkembangan Masyarakat. Bandung. Sinar Baru.1983.hal 3 politik hukum pidana berarti mengadakan pemilihan untuk mencapai hasil perundangan yang paling baik dalam arti memenuhi rasa keadilan dan daya guna.

4. melaksanakan politik hukum pidana dapat juga berarti usaha mewujudkan peraturan perundangundangan pidana yang sesuai dengan kaedah dan situasi pada suatu waktu dan untuk masa-masa yang akan datang.

\section{Pembahasan}

Kebijakan Narkotika menjadi bahan obat-obatan sudah ada sebelum Indonesia merdeka, dalam Undang-undang Nomor 35 Tahun 2009 tentang Narkotika (selanjutnya disebut Undang-undang Narkotika) mengatakan bahwa untuk meningkatkan derajat kesehatan sumber daya manusia Indonesia dalam rangka mewujudkan kesejahteraan rakyat perlu dilakukan upaya peningkatan di bidang pengobatan dan pelayanan 
kesehatan, antara lain dengan mengusahakan ketersediaan Narkotika jenis tertentu yang sangat dibutuhkan sebagai obat serta melakukan pencegahan dan pemberantasan bahaya penyalahgunaan dan peredaran gelap Narkotika dan Prekursor Narkotika, jika ganja ternyata dapat digunakan sebagai obat, kenapa harus dilarang pengunaannya.

Penulis juga tidak setuju jika Narkotika disalah gunakan untuk pemakaian yang menimbulkan ketergantungan, untuk itu perlu adanya kebijakan formulasi yang mengatur, sebagaimana disebutkan dalam konsideran Undang-undang Narkotika, bahwa Narkotika di satu sisi merupakan obat atau bahan yang bermanfaat di bidang pengobatan atau pelayanan kesehatan dan pengembangan ilmu pengetahuan dan di sisi lain dapat pula menimbulkan ketergantungan yang sangat merugikan apabila disalahgunakan atau digunakan tanpa pengendalian dan pengawasan yang ketat dan saksama;

Sudarto mengatakan bahwa suatu kejahatan yang dikatagorikan sebagai tindak pidana haruslah dilakukan melalui Politik Hukum yaitu :

a. Usaha untuk mewujudkan peraturan peraturan yang baik sesuai dengan keadaan dan situasi pada suatu saat. $^{4}$

b. Kebijakan dari Negara melalui badan badan yang berwenang untuk menetapkan peraturan perundang-undangan yang dikehendaki yang diperkirakan bisa digunakan untuk mengekspresikan apa yang terkandung di dalam masyarakat dan untuk mencapai apa yang dicita-citakan. $^{5}$

Hal tersebut diatas, bahwa kebijakan formulasi hukum pidana yang berupaya untuk mencapai tujuannya melalui kebijakan kriminal dengan menggunakan sarana penal

4 Sudarto, Hukum dan Hukum Pidana, Alumni, Bandung, 1981, hal 15

5 Sudarto, Hukum Pidana dan Pekembangan Masyarakat, Sinar Baru, Bandung 1983 hal. 20 
(hukum pidana), yang digunakan sebagai pendekatan dalam penanggulangan kejahatan tersebut. Hal ini merupakan pembentukan hukum baru yang mengkriminalisasikan atau mendekriminalisasikan (kriminalisasi atau dekriminalisasi) suatu perbuatan yang dapat dijadikan sebagai tindak pidana. Dekriminalisasi untuk sebuah perbuatan yang dulu merupakan tindak pidana, sekarang bukan lagi tindak pidana. ${ }^{6}$

Kebijakan formulasi pada saat ini dalam pengunaan narkotika diatur dalam Undang-undang Nomor 35 Tahun 2009 tentang tentang Narkotika membagi narkotika kedalam beberapa golongan yaitu :

a. Narkotika golongan I, adalah narkotika yang hanya dapat digunakan untuk tujuan pengembangan ilmu pengetahuan dan tidak digunakan dalam terapi, serta mempunyai potensi

\footnotetext{
6 Erwin Ubwarin, Kebijakan Formulasi Hukum Pidana Dalam Melanggulagi Kejahatan Skimming ATM, Jurnal Sasi, Vo. 21. No.2, Tahun 2015. Hal $17-20$
}

sangat tinggi ketergantungan.

b. Narkotika Golongan II, adalah narkotika berkhasiat pengobatan digunakan sebagai pilihan terakhir dan dapat digunakan sebagai terapi dan/atau untuk tujuan pengambagan ilmu pengetahuan serta mempunyai potensi sangat tinggi ketergantungan.

c. Narkotika Golongan III, adalah narkotika berkhasiat pengobatan dan banyak digunakan dalam terapi dan/atau untuk tujuan pengembangan ilmu pengetahuan serta mempunyai potensi ringan mengakibatkan ketergantungan. (vide penjelasan pasal 6 ayat (1)).

Dalam Lampiran Peraturan Menteri Kesehatan Nomor 50 Tahun 2018 
tentang Perubahan Penggolongan

Narkotika menyebutkan bahwa :

Tanaman ganja, semua

tanaman genus genus

cannabis dan semua bagian

dari tanaman termasuk biji,

buah, jerami, hasil olahan

tanaman ganja atau bagian

tanaman ganja termasuk

damar ganja dan hasis.

Ganja termasuk dalam Narkotika Golongan I, itu berarti ganja tidak bisa dijadikan sebagai obat atau terapi dalam penyembuhan pasien yang membutuhkannya. Adapun beberapa penyakit yang dalam penelitian terbukti dapat sembuh dengan menggunakan ganja yaitu :

1. Glaukoma

Glaukoma adalah kerusakan saraf mata akibat meningkatnya tekanan pada bola mata. Meningkatnya tekanan bola mata ini terjadi akibat gangguan pada sistem aliran cairan mata. Seseorang yang menderita kondisi ini dapat merasakan gejala berupa gangguan penglihatan, nyeri pada mata, hingga sakit kepala.

American Glaucoma Society dan Canada Ophthalmological Society merilis tulisan pada tahun 2010 bahwa ada kemanjuran ganja medis untuk pengobatan glaucoma. Ganja mendis menguragi tekanan pada mata (IOP) dan melindungi saraf retina agar tidak rusak karena glaucoma. ${ }^{7} \quad$ Ganja mengandung zat aktif tetrahidrokanabinol

(THC), Kandungan THC ini yang membantu untuk mengurangi tekanan dan melindungi retina dari

Henry Jampel, "American Glaucoma Society Position Statement: Marijuana and the Treatment of Glaucoma," Journal of Glaucoma 19, no. 2 (2010): 7576; and Yvonne M. Buys and Paul E. Rafuse,"Canadian Ophthalmological Society Policy Statement on the Medical Use of Marijuana for Glaucoma,"Canadian Journal of Ophthalmology/Journal Canadien d'Ophtalmologie 45, no. 4 (2010): 324-26. 


\begin{abstract}
kerusakan akibat
glaukoma, jika dilakukan

terapi dengan baik maka

ganja dapat mengobati

glaukoma. $^{8}$ Namun di

Indonesia tidak mungkin

dokter menganjurkan

membeli ganja.
\end{abstract}

2. Alzheimer's Disease

Penurunan daya ingat sering kita liat pada orang tua yang usia mereka memasuki 65 Tahun, orang tua kita terkenal sebuah penyakit, penyakit itu disebut Alzheimer, ini adalah penyakit otak yang

\section{mengakibatkan penurun}

an daya ingat, kemampuan berpikir dan bicara. V. A. Campbell and A. Gowran dalam penelitiannya menemukan bahwa ganja mempunyai

${ }^{8}$ Ileana Tomida, A. Azuara-Blanco, H. House, M. Flint, R. G. Pertwee, and P. J. Robson, "Effect of Sublingual Application of Cannabinoids on Intraocular Pressure: A Pilot Study," Journal of Glaucoma 15, no.5 (2006): 349-53. senyawa bernama

cannabinoid atau THC,

cannabinoid diyakini

dapat membantu

penanganan penurunan

daya ingat karena usia

manusia. Pengunaan

ganja membantu pasien

untuk tidur dengan

nyenyak, meningkatkan

nafsu makan. ${ }^{9}$

3. Fibromyalgia

Fibromyalgia adalah gangguan rematik, seperti artritis. Ini ditandai dengan rasa sakit di seluruh tubuh, respon tinggi dan menyakitkan tekanan, insomnia, kekakuan otot di pagi hari, dan kelelahan Sejumlah faktor yang terlibat, termasuk kelainan sistem saraf dan endokrin, faktor genetik. ${ }^{10}$

9 V. A. Campbell and A. Gowran, "Alzheimer's Disease; Taking the Edge Off with Cannabinoids?," British Journal of Pharmacology 152, no. 5 (November 2007): 655-62, doi:10.1038/sj.bjp.0707446.

10 Laurence A. Bradley, "Pathophysiology of Fibromyalgia," American Journal of Medicine 122, no. 12 (2009): hal 22-30. 


\begin{abstract}
Cannabinoid membuat pasien yang menderita Fibromyalgia mengalami pengurangan rasa sakit dan membuat pasien yang susah tidur menjadi lebih mudah tidur.
\end{abstract}

Tabel I

Negara Bagian di Amerika yang telah melegalkan Ganja sebagai tanaman medis

\begin{tabular}{|l|l|l|l|}
\hline No & Negara & Tahun & $\begin{array}{l}\text { Kondisi Yang } \\
\text { Diperbolehkan } \\
\text { memakaian } \\
\text { Ganja Medis }\end{array}$ \\
\hline 1 & Alaska & 1998 & $\begin{array}{l}\text { Cachexia, } \\
\text { cancer, } \\
\text { chronic pain, } \\
\text { epilepsy and } \\
\text { other } \\
\text { disorders } \\
\text { characterized } \\
\text { by seizures, } \\
\text { glaucoma, } \\
\text { HIV/AIDS, MS } \\
\text { and other } \\
\text { disorders } \\
\text { characterized } \\
\text { by muscle } \\
\text { spasticity, and } \\
\text { nausea; other } \\
\text { conditions are } \\
\text { subject to } \\
\text { approval by } \\
\text { the Alaska } \\
\text { Department of } \\
\text { Health and } \\
\text { Social Services } \\
\text { Cancer, } \\
\text { glaucoma, } \\
\text { HIV/AIDS, C, } \\
\text { hepatitis C }\end{array}$ \\
\hline 2 & Arizona & 2010 \\
\hline
\end{tabular}

\begin{tabular}{|l|l|l|}
\hline & & \\
& & ALS, Crohn \\
disease, \\
Alzheimer \\
disease, \\
cachexia, \\
severe and \\
chronic pain, \\
severe nausea, \\
seizures \\
(including \\
epilepsy), \\
severe \\
persistent \\
muscle spasms \\
\hline 3
\end{tabular}




\begin{tabular}{|c|c|c|c|}
\hline & & & $\begin{array}{l}\text { muscle spasms } \\
\text { (including } \\
\text { those } \\
\text { characteristic } \\
\text { of MS); other } \\
\text { conditions are } \\
\text { subject to } \\
\text { approval by } \\
\text { the Colorado } \\
\text { Board of } \\
\text { Health }\end{array}$ \\
\hline 5 & $\begin{array}{l}\text { Connecti } \\
\text { cut }\end{array}$ & 2012 & $\begin{array}{l}\text { Cancer, } \\
\text { glaucoma, } \\
\text { HIV/AIDS, } \\
\text { Parkinson } \\
\text { disease, MS, } \\
\text { damage to the } \\
\text { nervous tissue } \\
\text { of the spinal } \\
\text { cord with } \\
\text { objective } \\
\text { neurological } \\
\text { indication of } \\
\text { intractable } \\
\text { spasticity, } \\
\text { epilepsy, } \\
\text { cachexia, } \\
\text { Crohn disease, } \\
\text { PTSD, or any } \\
\text { medical }\end{array}$ \\
\hline 6 & $\begin{array}{l}\text { Washing } \\
\text { ton, DC }\end{array}$ & 2010 & $\begin{array}{l}\text { HIV/AIDS, } \\
\text { cancer, } \\
\text { glaucoma, } \\
\text { conditions } \\
\text { characterized } \\
\text { by severe and } \\
\text { persistent } \\
\text { muscle spasms } \\
\text { such as MS, } \\
\text { patients } \\
\text { undergoing } \\
\text { chemotherapy } \\
\text { or } \\
\text { radiotherapy } \\
\text { or using } \\
\text { azidothymidin } \\
\text { e or protease } \\
\text { inhibitors }\end{array}$ \\
\hline 7 & $\begin{array}{l}\text { Delawar } \\
\mathrm{e}\end{array}$ & 2011 & $\begin{array}{l}\text { Cancer, } \\
\text { HIV/AIDS, }\end{array}$ \\
\hline
\end{tabular}

\begin{tabular}{|c|c|c|c|}
\hline & & & $\begin{array}{l}\text { decompensate } \\
d \quad \text { cirrhosis } \\
\text { (hepatitis C), } \\
\text { ALS, } \\
\text { Alzheimer } \\
\text { disease A } \\
\text { chronic or } \\
\text { debilitating } \\
\text { disease or } \\
\text { medical } \\
\text { condition or } \\
\text { its treatment } \\
\text { that produces } \\
\geq 1 \quad \text { of the } \\
\text { following: } \\
\text { cachexia; } \\
\text { severe, } \\
\text { debilitating } \\
\text { pain that has } \\
\text { not responded } \\
\text { to previously } \\
\text { prescribed } \\
\text { medication or } \\
\text { surgical } \\
\text { measures for } \\
\text { more than } 3 \\
\text { mo or for } \\
\text { which other } \\
\text { treatment } \\
\text { options } \\
\text { produced } \\
\text { serious } \\
\text { adverse } \\
\text { effects; } \\
\text { intractable } \\
\text { nausea; } \\
\text { seizures; } \\
\text { severe and } \\
\text { persistent } \\
\text { muscle spasms } \\
\text { including but } \\
\text { not limited to } \\
\text { those } \\
\text { characteristic } \\
\text { of MS } \\
\end{array}$ \\
\hline 8 & Huwai & 2000 & $\begin{array}{l}\text { Cancer, } \\
\text { glaucoma, } \\
\text { HIV/AIDS, a } \\
\text { chronic } \\
\text { debilitating }\end{array}$ \\
\hline
\end{tabular}




\begin{tabular}{|c|c|c|c|}
\hline & & & $\begin{array}{l}\text { disease or } \\
\text { medical } \\
\text { condition or } \\
\text { its treatment } \\
\text { that produces } \\
\text { cachexia, } \\
\text { severe pain, } \\
\text { severe nausea, } \\
\text { seizures } \\
\text { including } \\
\text { those } \\
\text { characteristic } \\
\text { of epilepsy, or } \\
\text { severe and } \\
\text { persistent } \\
\text { muscle spasms } \\
\text { including } \\
\text { those } \\
\text { characteristic } \\
\text { of MS or } \\
\text { Crohn disease; } \\
\text { other } \\
\text { conditions are } \\
\text { subject to } \\
\text { approval by } \\
\text { the Hawaii } \\
\text { Department of } \\
\text { Health }\end{array}$ \\
\hline 9 & Illinois & 2013 & $\begin{array}{l}\text { Cancer, } \\
\text { glaucoma, } \\
\text { HIV/AIDS, } \\
\text { hepatitis C, } \\
\text { ALS, Crohn } \\
\text { disease, } \\
\text { agitation } \\
\text { related to } \\
\text { Alzheimer } \\
\text { disease, } \\
\text { cachexia/wasti } \\
\text { ng syndrome, } \\
\text { muscular } \\
\text { dystrophy, } \\
\text { severe } \\
\text { fibromyalgia, } \\
\text { spinal cord } \\
\text { disease } \\
\text { (including } \\
\text { but not limited } \\
\text { to } \\
\text { arachnoiditis), }\end{array}$ \\
\hline
\end{tabular}

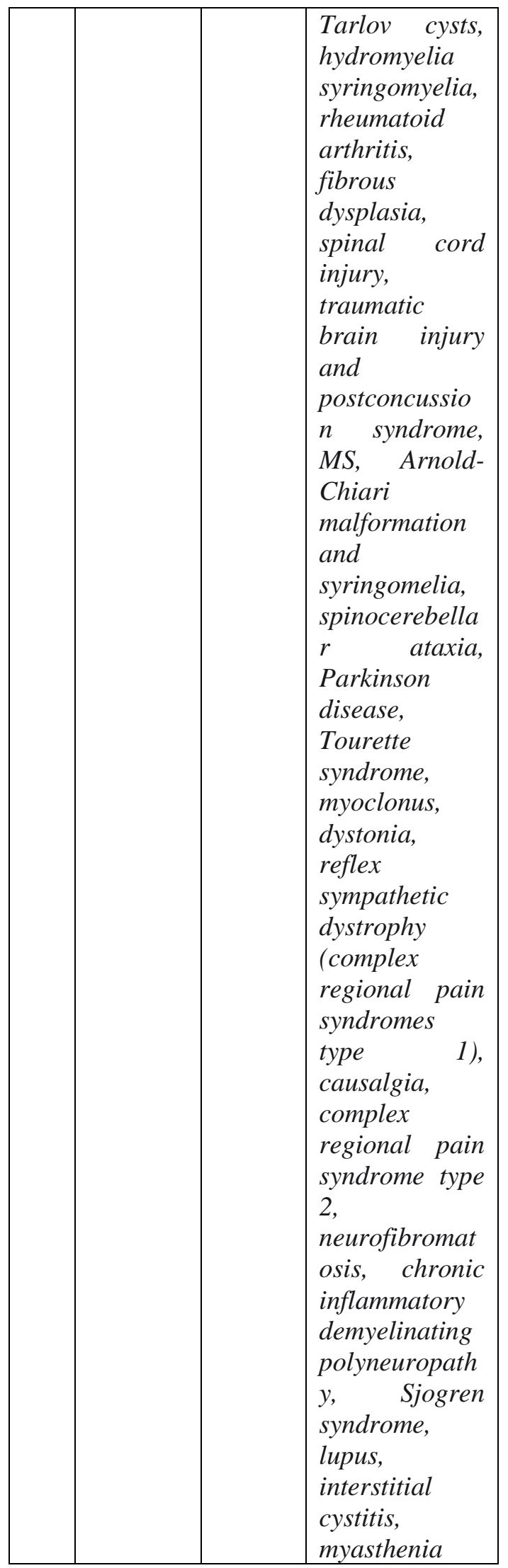




\begin{tabular}{|c|c|c|c|}
\hline & & & $\begin{array}{l}\text { gravis, } \\
\text { hydrocephalus } \\
\text {, nail patella } \\
\text { syndrome or } \\
\text { residual limb } \\
\text { pain, or } \\
\text { treatment of } \\
\text { these } \\
\text { conditions }\end{array}$ \\
\hline 10 & Maine & 1999 & $\begin{array}{l}\text { Epilepsy and } \\
\text { other } \\
\text { disorders } \\
\text { characterized } \\
\text { by seizures, } \\
\text { glaucoma, MS } \\
\text { and other } \\
\text { disorders } \\
\text { characterized } \\
\text { by muscle } \\
\text { spasticity, and } \\
\text { nausea or } \\
\text { vomiting as a } \\
\text { result of AIDS } \\
\text { or cancer } \\
\text { chemotherapy }\end{array}$ \\
\hline 11 & $\begin{array}{l}\text { Marylan } \\
\text { d }\end{array}$ & 2014 & $\begin{array}{l}\text { Cachexia, } \\
\text { anorexia, or } \\
\text { wasting } \\
\text { syndrome, } \\
\text { severe or } \\
\text { chronic pain, } \\
\text { severe nausea, } \\
\text { seizures, } \\
\text { severe or } \\
\text { persistent } \\
\text { muscle } \\
\text { spasms, or } \\
\text { other } \\
\text { conditions } \\
\text { approved by } \\
\text { the } \\
\text { commission }\end{array}$ \\
\hline 12 & $\begin{array}{l}\text { Massach } \\
\text { usetts }\end{array}$ & 2012 & $\begin{array}{l}\text { Cancer, } \\
\text { glaucoma, } \\
\text { HIV/AIDS, } \\
\text { hepatitis C, } \\
\text { ALS, Crohn } \\
\text { disease, } \\
\text { Parkinson } \\
\text { disease, MS, }\end{array}$ \\
\hline
\end{tabular}

\begin{tabular}{|c|c|c|c|}
\hline & & & $\begin{array}{l}\text { and other } \\
\text { conditions as } \\
\text { determined in } \\
\text { writing by a } \\
\text { qualifying } \\
\text { patient's } \\
\text { physician }\end{array}$ \\
\hline 13 & $\begin{array}{l}\text { Michiga } \\
\mathrm{n}\end{array}$ & 2008 & $\begin{array}{l}\text { Cancer, } \\
\text { glaucoma, } \\
\text { HIV/AIDS, } \\
\text { hepatitis C, } \\
\text { ALS, Crohn } \\
\text { disease, } \\
\text { agitation of } \\
\text { Alzheimer } \\
\text { disease, nail } \\
\text { patella } \\
\text { syndrome, } \\
\text { cachexia or } \\
\text { wasting } \\
\text { syndrome, } \\
\text { severe and } \\
\text { chronic pain, } \\
\text { severe nausea, } \\
\text { seizures, } \\
\text { epilepsy, } \\
\text { muscle } \\
\text { spasms, MS, } \\
\text { PTSD }\end{array}$ \\
\hline 14 & $\begin{array}{l}\text { Minneso } \\
\text { ta, }\end{array}$ & 2004 & $\begin{array}{l}\text { Cancer (if the } \\
\text { underlying } \\
\text { condition or } \\
\text { treatment } \\
\text { produces } \\
\text { severe or } \\
\text { chronic pain, } \\
\text { nausea, severe } \\
\text { vomiting, or } \\
\text { cachexia or } \\
\text { severe } \\
\text { wasting), } \\
\text { glaucoma, } \\
\text { HIV/AIDS, } \\
\text { Tourette } \\
\text { syndrome, } \\
\text { ALS, } \\
\text { seizures/epilep } \\
\text { sy, severe and } \\
\text { persistent } \\
\text { muscle }\end{array}$ \\
\hline
\end{tabular}




\begin{tabular}{|c|c|c|c|}
\hline & & & $\begin{array}{l}\text { spasms/MS, } \\
\text { Crohn disease, } \\
\text { terminal } \\
\text { illness with a } \\
\text { life } \\
\text { expectancy of } \\
<1 y\end{array}$ \\
\hline 15 & Montana & 2004 & $\begin{array}{l}\text { Cancer, } \\
\text { glaucoma, } \\
\text { HIV/AIDS, or } \\
\text { the treatment } \\
\text { of these } \\
\text { conditions; } \\
\text { cachexia or } \\
\text { wasting } \\
\text { syndrome, } \\
\text { severe or } \\
\text { chronic pain, } \\
\text { severe nausea, } \\
\text { seizures } \\
\text { including } \\
\text { those caused } \\
\text { by epilepsy, } \\
\text { severe or } \\
\text { persistent } \\
\text { muscle spasms } \\
\text { including } \\
\text { those caused } \\
\text { by MS or } \\
\text { Crohn disease, } \\
\text { or any other } \\
\text { medical } \\
\text { condition or } \\
\text { treatment for a } \\
\text { medical } \\
\text { condition } \\
\text { adopted by the } \\
\text { department by } \\
\text { rule }\end{array}$ \\
\hline 16 & Nevada & 2000 & $\begin{array}{l}\text { AIDS, cancer, } \\
\text { glaucoma, and } \\
\text { any medical } \\
\text { condition or } \\
\text { treatment for a } \\
\text { medical } \\
\text { condition that } \\
\text { produces } \\
\text { cachexia, } \\
\text { persistent } \\
\text { muscle spasms }\end{array}$ \\
\hline
\end{tabular}

\begin{tabular}{|c|c|c|c|}
\hline & & & $\begin{array}{l}\text { or seizures, } \\
\text { severe nausea } \\
\text { or pain, } \\
\text { PTSD; other } \\
\text { conditions are } \\
\text { subject to } \\
\text { approval by } \\
\text { the health } \\
\text { division of the } \\
\text { state } \\
\text { department of } \\
\text { human } \\
\text { resources }\end{array}$ \\
\hline 17 & $\begin{array}{l}\text { New } \\
\text { Hampshi } \\
\text { re }\end{array}$ & 2013 & $\begin{array}{l}\text { Cancer, } \\
\text { glaucoma, } \\
\text { HIV/AIDS, } \\
\text { hepatitis C, } \\
\text { ALS, muscular } \\
\text { dystrophy, } \\
\text { Crohn disease, } \\
\text { agitation of } \\
\text { Alzheimer } \\
\text { disease, MS, } \\
\text { chronic } \\
\text { pancreatitis, } \\
\text { spinal cord } \\
\text { injury or } \\
\text { disease, } \\
\text { traumatic } \\
\text { brain injury, } \\
\text { or } \geq 1 \text { injuries } \\
\text { that significantly } \\
\text { interferes with } \\
\text { daily activities } \\
\text { as documented } \\
\text { by the } \\
\text { patient's } \\
\text { clinician; a } \\
\text { severely } \\
\text { debilitating or } \\
\text { terminal } \\
\text { medical } \\
\text { condition or } \\
\text { its treatment } \\
\text { that has } \\
\text { produced } \geq 1 \text { of } \\
\text { the following: } \\
\text { elevated } \\
\text { intraocular }\end{array}$ \\
\hline
\end{tabular}




\begin{tabular}{|c|c|c|c|}
\hline & & & $\begin{array}{l}\text { pressure, } \\
\text { cachexia, } \\
\text { chemotherapy } \\
\text { induced } \\
\text { anorexia, } \\
\text { wasting } \\
\text { syndrome, } \\
\text { severe pain } \\
\text { not responding } \\
\text { to previously } \\
\text { prescribed } \\
\text { medication or } \\
\text { surgical } \\
\text { measures or } \\
\text { for } \\
\text { other which } \\
\text { treatment } \\
\text { options } \\
\text { produced } \\
\text { serious } \\
\text { adverse } \\
\text { effects, } \\
\text { constant or } \\
\text { severe nausea, } \\
\text { moderate to } \\
\text { severe } \\
\text { vomiting, } \\
\text { seizures, } \\
\text { severe, } \\
\text { persistent } \\
\text { muscle spasms }\end{array}$ \\
\hline 18 & $\begin{array}{l}\text { New } \\
\text { Jersey }\end{array}$ & 2010 & $\begin{array}{l}\text { Seizure } \\
\text { disorder } \\
\text { including } \\
\text { epilepsy, } \\
\text { intractable } \\
\text { skeletal } \\
\text { muscular } \\
\text { spasticity, } \\
\text { glaucoma, } \\
\text { severe or } \\
\text { chronic pain, } \\
\text { severe nausea } \\
\text { or vomiting, } \\
\text { cachexia or } \\
\text { wasting } \\
\text { syndrome } \\
\text { resulting from } \\
\text { HIV/AIDS or } \\
\text { cancer, ALS, }\end{array}$ \\
\hline
\end{tabular}

\begin{tabular}{|c|c|c|c|}
\hline & & & $\begin{array}{l}\text { MS, terminal } \\
\text { cancer, } \\
\text { muscular } \\
\text { dystrophy, } \\
\text { IBD including } \\
\text { Crohn disease, } \\
\text { terminal } \\
\text { illness } \\
\text { (physician- } \\
\text { determined } \\
\text { prognosis of } \\
<12 \text { mo of } \\
\text { life), or any } \\
\text { other medical } \\
\text { condition or } \\
\text { its treatment } \\
\text { approved by } \\
\text { the } \\
\text { Department of } \\
\text { Health and } \\
\text { Senior } \\
\text { Services }\end{array}$ \\
\hline 19 & $\begin{array}{l}\text { New } \\
\text { Mexico }\end{array}$ & 2007 & $\begin{array}{l}\text { Severe chronic } \\
\text { pain, painful } \\
\text { peripheral } \\
\text { neuropathy, } \\
\text { intractable } \\
\text { nausea/vomiti } \\
\text { ng, severe } \\
\text { anorexia/cach } \\
\text { exia, hepatitis } \\
\text { C, Crohn } \\
\text { disease, PTSD, } \\
\text { ALS, cancer, } \\
\text { glaucoma, MS, } \\
\text { damage to the } \\
\text { nervous tissue } \\
\text { of the spinal } \\
\text { cord with } \\
\text { intractable } \\
\text { spasticity, } \\
\text { epilepsy, } \\
\text { HIV/AIDS, } \\
\text { hospice care, } \\
\text { cervical } \\
\text { dystonia, } \\
\text { inflammatory } \\
\text { autoimmune- } \\
\text { mediated } \\
\text { arthritis, }\end{array}$ \\
\hline
\end{tabular}




\begin{tabular}{|c|c|c|c|}
\hline & & & $\begin{array}{l}\text { Parkinson } \\
\text { disease, } \\
\text { Huntington } \\
\text { disease }\end{array}$ \\
\hline 20 & $\begin{array}{l}\text { New } \\
\text { York }\end{array}$ & 2014 & $\begin{array}{l}\text { Cancer, } \\
\text { HIV/AIDS, } \\
\text { ALS, } \\
\text { Parkinson } \\
\text { disease, MS, } \\
\text { spinal cord } \\
\text { damage } \\
\text { causing } \\
\text { spasticity, } \\
\text { epilepsy, IBD, } \\
\text { neuropathies, } \\
\text { Huntington } \\
\text { disease The } \\
\text { Department of } \\
\text { Health } \\
\text { commissioner } \\
\text { has the } \\
\text { discretion to } \\
\text { add or delete } \\
\text { conditions and } \\
\text { must decide } \\
\text { whether to add } \\
\text { Alzheimer } \\
\text { disease, } \\
\text { muscular } \\
\text { dystrophy, } \\
\text { dystonia, and } \\
\text { PTSD, and } \\
\text { rheumatoid } \\
\text { arthritis within } \\
\text { 18 mo of the } \\
\text { law becoming } \\
\text { effective }\end{array}$ \\
\hline 21 & Oregon & 1998 & $\begin{array}{l}\text { Cancer, } \\
\text { glaucoma, } \\
\text { HIV/AIDS, or } \\
\text { treatment of } \\
\text { these } \\
\text { conditions; a } \\
\text { medical } \\
\text { condition or } \\
\text { treatment for a } \\
\text { medical } \\
\text { condition that } \\
\text { produces } \\
\text { cachexia, }\end{array}$ \\
\hline
\end{tabular}

\begin{tabular}{|c|c|c|c|}
\hline & & & $\begin{array}{l}\text { severe pain, } \\
\text { severe nausea, } \\
\text { seizures } \\
\text { including } \\
\text { those caused } \\
\text { by epilepsy, or } \\
\text { persistent } \\
\text { muscle spasms } \\
\text { including } \\
\text { those caused } \\
\text { by MS; other } \\
\text { conditions are } \\
\text { subject to } \\
\text { approval by } \\
\text { the Health } \\
\text { Division of the } \\
\text { Oregon } \\
\text { Department of } \\
\text { Human } \\
\text { Resources }\end{array}$ \\
\hline 22 & $\begin{array}{l}\text { Rhode } \\
\text { Island }\end{array}$ & 2006 & $\begin{array}{l}\text { Cancer, } \\
\text { glaucoma, } \\
\text { HIV/AIDS, } \\
\text { hepatitis C, or } \\
\text { treatment of } \\
\text { these } \\
\text { conditions; a } \\
\text { chronic or } \\
\text { debilitating } \\
\text { disease or } \\
\text { medical } \\
\text { condition or } \\
\text { its treatment } \\
\text { that produces } \\
\text { cachexia or } \\
\text { wasting } \\
\text { syndrome, } \\
\text { severe } \\
\text { debilitating } \\
\text { chronic pain, } \\
\text { severe nausea, } \\
\text { seizures } \\
\text { including but } \\
\text { not limited to } \\
\text { those } \\
\text { characteristic } \\
\text { of epilepsy, or } \\
\text { severe and } \\
\text { persistent } \\
\text { muscle spasms }\end{array}$ \\
\hline
\end{tabular}




\begin{tabular}{|c|c|c|c|}
\hline & & & $\begin{array}{l}\text { including but } \\
\text { not limited to } \\
\text { those } \\
\text { characteristic } \\
\text { of MS or } \\
\text { Crohn disease, } \\
\text { agitation of } \\
\text { Alzheimer } \\
\text { disea }\end{array}$ \\
\hline 23 & Vermont & 2004 & $\begin{array}{l}\text { Cancer, } \\
\text { HIV/AIDS, } \\
\text { MS, or the } \\
\text { treatment of } \\
\text { these } \\
\text { conditions if } \\
\text { the disease or } \\
\text { the treatment } \\
\text { results in } \\
\text { severe, } \\
\text { persistent, and } \\
\text { intractable } \\
\text { symptoms; a } \\
\text { disease, } \\
\text { medical } \\
\text { condition, or } \\
\text { its treatment } \\
\text { that is chronic, } \\
\text { debilitating, } \\
\text { and produces } \\
\geq 1 \quad \text { severe, } \\
\text { persistent, } \\
\text { intractable } \\
\text { symptoms of } \\
\text { cachexia or } \\
\text { wasting } \\
\text { syndrome, } \\
\text { severe pain or } \\
\text { nausea, or } \\
\text { seizures }\end{array}$ \\
\hline 24 & $\begin{array}{l}\text { Washing } \\
\text { ton }\end{array}$ & 1998 & $\begin{array}{l}\text { Cachexia, } \\
\text { cancer, } \\
\text { HIV/AIDS, } \\
\text { epilepsy, } \\
\text { glaucoma, } \\
\text { intractable } \\
\text { pain (defined } \\
\text { as pain } \\
\text { unrelieved by } \\
\text { standard } \\
\text { treatment or }\end{array}$ \\
\hline
\end{tabular}

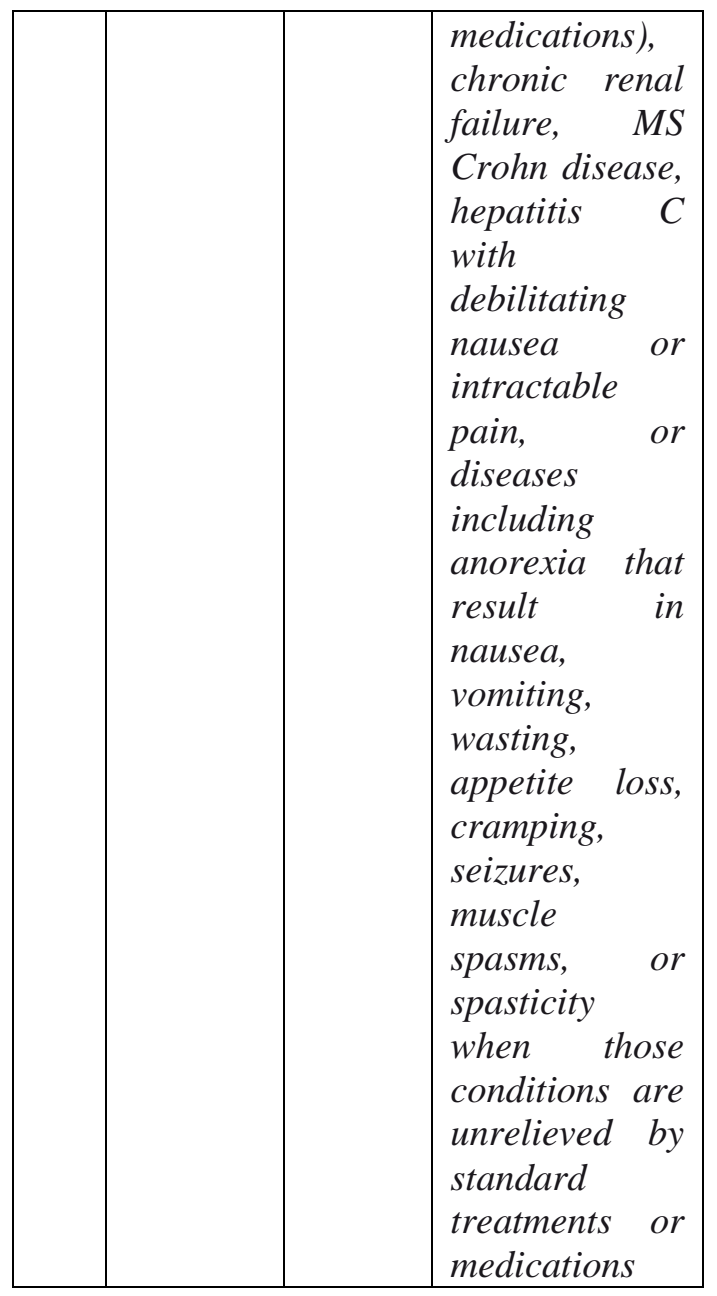

Sumber:http://medicalmarijuana.pr ocon.org/view.resoure.php?resource ID $=000881$

Pengaturan di 22 Negara bagian juga tidak sama dalam hal jumlah pemakaian jenis penyakit yang bisa digunakan ganja sebagai pengobatan. Contoh di Arizona, yang melegalkan ganja pada tahun 2010, batas pemakaian ganja hanya 2.5 Ons sedangkan Nevada batas pemakaian hanya 1 Ons, berbeda juga dengan Washington batas pemakaian ganja medis 24 Ons. 
Negara bagian Arizona di Amerika contohnya, telah melegalkan ganja sebagai tanaman obat yang memberikan manfaat besar untuk menanggani berberapa penyakit, namun pengawasan mengenai pemakaian ini juga menjadi hal yang tidak terpisakan, Ariziona memakai kartu kepada pasien yang direkomendasikan dokter untuk memakai ganja medis, jadi ketika ia ke apotik dia menunjukan.

Dengan melihat hasil penelitian dan penerapan pengaturan ganja medis di atas maka penulis sampai pada kesimpulan awal bahwa perlu dilakukan kebijakan formulasi hukum pidana untuk merevisi Undang-undang Nomor 35 Tahun 2009 tentang Narkotika. Kebijakan Formulasi Hukum Pidana bukan saja berbicara tentang kebijakan hukum pidana yang terjadi saat ini namun juga masa yang akan datang. ${ }^{11}$

Usaha Pembahuruan hukum di Indonesia yang sudah dimulai sejak lahirnya UUD'45 tidak dapat

\footnotetext{
11 Erwin Ubwarin, Kebijakan

Formulasi Hukum Pidana Dalam Melanggulagi Kejahatan Skimming Atm. Jurnal Sasi Vol.21 No.2 Bulan Juli Desember 2015.hal 19
}

dilepaskan pula dari landasan dan sekaligus tujuan yang ingin dicapai seperti telah pula dari landasan dan sekaligus tujuan yang ingin dicapai seperti yang telah dirumuskan juga dalam Pembukaan UUD/45. Tujuan yang telah digariskan dalam pembukaan UUD/45 itu secara singkat ialah "melindungi segenap bangsa Indonesia dan untuk memajukan kesejahteraan umum berdasarkan Pancasila”. Inilah garis kebijakan umum yang menjadi landasan dan sekaligus tujuan politik hukum di Indonesia. Ini pula yang menjadi landasan dan tujuan dari setiap usaha pembaharuan hukum, termasuk pembaharuan di bidang hukum pidana dan kebijakan penangulangan hukum di Indonesia. $^{12}$

Kebutuhan pembahuruan hukum pidana sangat penting dilaksanakan, hukum pidana harus memuat tentang aturan-aturan hukum yang mengikat perbuatan-perbuatan yang memenuhi syarat tertentu pada

\footnotetext{
${ }^{12}$ Barda Nawawi Arief, Kebijakan Legislatif Dalam Penangulangan Kejahatan Dengan Pidana Penjara, GENTA, Yogyakarta, 2010. Hal 1-2.
} 
suatu akibat berupa pidana. ${ }^{13}$ Bagaimana suatu perbuatan dikatakan perbuatan pidana apabila, perbuatan tersebut belum diatur dalam undang-undang, pembuatan undang-undang sangat berkaitan dengan kebijakan legislasi/formulitf. ${ }^{14}$ Perlu diatur tentang legalisasi ganja sebagai bahan pengobatan, karena pengaturan sekarang masih menempatkan ganja sebagai golongan narkotika yang diperbolehkan sebagai bahan kesehatan.

\section{Pasal $37 \quad$ Undang-undang} Nomor 35 Tahun 2009 mengatur bahwa hanya Narkotika Golongan II dan III yang dapat dijadikan sebagai bahan obat. Lebih lanjut dalam Pasal 53 Undang-undang Nomor 35 Tahun 2009 mengatur soal pengunaan Narkotika II dan III dalam jumlah

13 Teguh Sulista dan Aria Zunetti, Hukum Pidana Horizon Baru Pasca Reformasi, Raja Grafindo Persada 2002, Hal 5

14 Erwin Ubwarin, Kebijakan

Formulasi Hukum Pidana Dalam Penanggulangan Tindak Pidana Perjudian Melalui Internet (Internet Gambling.) Jurnal Sasi Vol.21 No.1 Bulan Januari - Juni 2015. Hal 48 terbatas dapat digunakan sebagai bahan pengobatan.

Pasal 117 Undang-undang Nomor 35 Tahun 2009 sudah mengatur tentang memiliki, menyimpan, menguasai, atau menyediakan Narkotika Golongan II diancam dengan pidana penjara, sedangkan Pasal 118 mengatur tentang memproduksi, mengimpor, mengekspor, atau menyalurkan Narkotika Golongan II dijatuhi pidana. Pasal 122 sampai dengan Pasal 126 Undang-undang Nomor 35 Tahun 2009 mengatur tentang anjaman pidana bagi Narktika Golongan III.

Menurut Penulis Lampiran Undang-undang Nomor 35 Tahun 2009, harus direvisi dengan mengeluarkan tanaman ganja, semua tanaman genus genus cannabis dan semua bagian dari tanaman termasuk biji, buah, jerami, hasil olahan tanaman ganja atau bagian tanaman ganja termasuk damar ganja dan hasis, pindah ke narkotika golongan II agar dapat digunakan sebagai bahan medis.

\section{Penutup}




\begin{abstract}
Penulis tidak setuju dengan
ganja dijadikan bahan rekreasi, digunakan secara bebas tanpa ada batasan, namun penulis setuju bahwa harus ada kebijakan formulasi hukum pidana agar ganja pindah dari Gologan I ke Golongan II atau Golongan III, untuk kepentingan medis, ganja tidak bisa digunakan jika ada dalam Golongan I, karena itu perlu ada revisi Undang-undang Nomor 35 Tahun 2009 telah mengatur ganja tidak boleh dijadikan bahan medis.
\end{abstract}




\section{Daftar Pustka}

Arief, B. (2010). Kebijakan Legislatif Dalam Penangulangan Kejahatan Dengan Pidana Penjara. Yogyakarta: GENTA.

Bradley, L. A. (Vol 122, no. 12 (2009)). Pathophysiology of Fibromyalgia. American Journal of Medicine, hal 22-30. .

Buenz, E., Johnson, H. E., Beekman, E., \& Bauer, B. (2004). Bioprospecting Rumphiu's Ambonese Herbal. Jurnal of Etho-phramacologi .

Campbell , V. A. ;and A. Gowran. (Vol 152, no. 5 (November 2007)). Alzheimer's Disease; Taking the Edge Off with Cannabinoids? British Journal of Pharmacology, 655-62.

Eberhard, R. G. (1981). The Poison Tree Selected Writings of Rumphius on the Natural Hostory of The Indies. University of Massachusetts Pres.

Jampel, H. (Vol 19, no. 2 (2010)). "American Glaucoma Society Position Statement: Marijuana and the Treatment of Glaucoma," . Journal of Glaucoma , 75-76.

Sudarto. (1981). Hukum dan Hukum Pidana. Bandung: Alumni.

Sudarto. (1981). Kapita Selekta Hukum Pidana. Bandung: Alumni.

Tomida, I., A. Azuara-Blanco, \& H. House, M. F. (Vol 15, no.5 (2006)). Effect of Sublingual Application of Cannabinoids on Intraocular Pressure: A Pilot Study,” . Journal of Glaucoma , 349-53.

Ubwarin, E. (Vol.21 No.1 Bulan Januari - Juni 2015). ebijakan Formulasi Hukum Pidana Dalam Penanggulangan Tindak Pidana Perjudian Melalui Internet (Internet Gambling.). Jurnal Sasi , Hal 48.

Ubwarin, E. (2015 ). KEBIJAKAN FORMULASI HUKUM PIDANA DALAM MELANGGULAGI KEJAHATAN SKIMMING ATM. Jurnal Sasi Volume 21 Nomor 2.

Ubwarin, E. (Vol.21 No.2 Bulan Juli - Desember 2015). Kebijakan Formulasi Hukum Pidana Dalam Melanggulagi Kejahatan Skimming ATM. Jurnal Sasi .

Zunetti, T. S. (2002). Hukum Pidana Horizon Baru Pasca Reformasi,. Jakarta: Raja Grafindo Persada . 